\title{
Accumulation of Dry Matter and Nitrogen in Durum Wheat During Grain Filling as Affected by Temperature and Nitrogen Rate
}

\author{
Laura Ercoli ${ }^{*}$, Alessandro Masoni ${ }^{2}$, Marco Mariotti², Iduna Arduini ${ }^{2}$ \\ ${ }^{1}$ Scuola Superiore Sant'Anna, Piazza Martiri della Libertà 33, 56127 Pisa, Italy \\ ${ }^{2}$ Dipartimento di Agronomia e Gestione dell'Agroecosistema, Università di Pisa \\ Via San Michele degli Scalzi 2, 56124, Pisa, Italy
}

Received: 28 October 2008. Accepted: 21 January 2009.

\begin{abstract}
Durum wheat (Triticum durum Desf.) is commonly grown in mediterranean conditions, where temperature stress during grain filling can limit productivity. This study was conducted to assess the effect of optimal and too high temperature during grain filling on the patterns of accumulation of dry matter and $\mathrm{N}$ of durum wheat plants grown at different levels of $\mathrm{N}$ fertilization. Two durum wheat varieties, Appio and Creso, were grown in controlled environment conditions and in pots with three rates of nitrogen fertilizer (not applied, normal amount, and high amount) and two air temperature regimes during grain filling $\left(20 / 15{ }^{\circ} \mathrm{C}\right.$ and $28 / 23{ }^{\circ} \mathrm{C}$ day/night). Results showed that the duration of the intervals between the main maturity stages within grain filling were both genotype-specific and temperature-dependent, while $\mathrm{N}$ rate did not modify the timing of grain development. The two genotypes responded to temperature by increasing the rate of development, but the thermal timing of development was unchanged with the two temperature regimes. The higher temperature reduced grain growth and increased $\mathrm{N}$ accumulation in grain. However, these effects were recorded only in fertilized plants. Nitrogen availability modified the growth of the plant during the whole cycle, in that increased $\mathrm{N}$ fertilizer at seeding resulted in a greater plant size at anthesis and in a greater accumulation rate of dry matter and $\mathrm{N}$ in grain during grain filling. Grain yield and kernel weight were better expressed at $20 / 15^{\circ} \mathrm{C}$, while grain protein concentration was favoured under the $28 / 23{ }^{\circ} \mathrm{C}$ temperature regime. Nitrogen fertilization increased the sensitivity of plants to high temperature. Thus, the role of $\mathrm{N}$ fertilization under heat stress may be more important than under optimal temperatures.
\end{abstract}

Key-words: durum wheat, grain filling, nitrogen content, nitrogen fertilization, temperature.

\section{Introduction}

Wheat is grown around the world under a wide range of environmental conditions, where climatic factors, such as temperature and moisture, exert diverse effects on plant growth, which in turn affects yield and grain characteristics influencing grain quality (Dupont and Altenbach, 2003; Abad et al., 2004). In the southern regions of Italy, temperature following anthesis often exceeds that at which optimum biological activity occurs, thus high temperature reduces grain yield but increases $\mathrm{N}$ concentration in grain, improving its quality (Novaro et al., 1997; Corbellini et al., 1998). In the northern regions, on the contrary, under lower temperatures during grain filling, higher grain yield is produced but with lower $\mathrm{N}$ concentration in grain (Borghi et al., 1997).

Porter and Gawith (1999), in a literature review on the effects of temperature on the growth and development of wheat, identified the optimum temperature for grain filling in the range $19.3-22.1{ }^{\circ} \mathrm{C}$, and the maximum temperature between 33.4 and $37.4{ }^{\circ} \mathrm{C}$. These wide ranges of variation are determined not only by differences in experimental approach and design, but also by genotypic differences in tolerance to extreme temperatures, as wheat varieties originat-

\footnotetext{
* Corresponding Author: Tel.: +39 050 883357; Fax: +39 050 883215. E-mail address: ercoli@sssup.it
} 
ing from to diverse growing regions respond differently to environmental conditions (Sofield et al., 1977; Stone and Nicholas, 1995; Wardlaw and Moncur, 1995).

Temperature affects many plant processes, such as enzyme activities and photosynthesis, the rates and efficiencies of which are temperature-dependent. The thermal kinetic window for wheat, describing the temperature range for optimal enzyme functioning, has been identified as lying between 17.5 and $23{ }^{\circ} \mathrm{C}$ (Burke at al., 1988). The rate of photosynthesis is optimized at $25{ }^{\circ} \mathrm{C}$ and it declines at temperatures lower than $15{ }^{\circ} \mathrm{C}$ and higher than $30{ }^{\circ} \mathrm{C}$ (Wardlaw, 1974). However, distinct genetic variation exists both for leaf and ear carbon-exchange rates under heat stress, and it has been generally accepted that heat tolerance of photosynthesis is a primary reason for sustained grain filling and yield under heat stress (Alkhatib and Paulsen, 1992; Blum, 1994).

Many studies have attempted to quantify the negative effect of high temperature on wheat grain yield, both in field experiments (Wiegand and Cuellar, 1981; Peterson et al., 1998; Panozzo and Eagles, 1999; Vaccari et al., 2007) and in controlled growth experiments (Altenbach et al., 2003). Reduced grain yield with high temperature during grain filling was attributed to reduced mean kernel weight, caused by diminished deposition of starch in the grain (Stone and Nicholas, 1995; Plaut et al., 2004). Kernel number is generally not affected, since the value is already set by anthesis (Wardlaw et al., 1989). It is reported that high temperature negatively affect mean kernel weight by reducing both the duration and the rate of grain filling (Wiegand and Cuellar, 1981; Wardlaw and Moncur, 1995). The response of both processes to temperature varied with timing and duration of treatments, cultural conditions and also among varieties. For some Australian varieties, the increase of temperature from $15 / 10{ }^{\circ} \mathrm{C}$ to $21 / 16$ ${ }^{\circ} \mathrm{C}$ reduced the duration of grain filling but increased the rate of grain growth, with the result that there was little change in grain yield at maturity (Chowdury and Wardlaw, 1978). With a further rise in temperature from $21 / 16{ }^{\circ} \mathrm{C}$ to $33 / 28{ }^{\circ} \mathrm{C}$, indeed, large decreases in the duration of grain growth were accompanied by decreases in growth rate (Tashiro and Wardlaw, 1989). Guedira and Pauelsen (2002) observed a signif- icant decrease in kernel weight because the duration, but not the rate, of grain filling was reduced when plants were subjected to $30{ }^{\circ} \mathrm{C}$ instead to $15{ }^{\circ} \mathrm{C}$ during this period. Altenbach et al. (2003) demonstrated that high temperature during grain filling reduced the duration of many physiological processes, like water uptake, kernel expansion, dry weight accumulation and kernel desiccation. Starch accumulation also occurred earlier, while changes in the onset of protein accumulation were less clear.

The effect of temperature on current assimilation during grain filling and remobilization of pre-anthesis reserves can vary also with $\mathrm{N}$ availability, as differences in plant size due to $\mathrm{N}$ fertilization can affect the amount of accumulated and remobilized reserves within the plant $(\mathrm{Pa}-$ pakosta and Gagianas, 1991).

This research was performed to evaluate, in controlled conditions, the effect of temperature during grain filling on the patterns of dry matter and nitrogen accumulation of two durum wheat varieties, grown with different nitrogen availabilities from seeding. Our experiment compared two different temperature regimens, one within the normal range occurring during grain filling in Central Italy, the other within the normal range occurring in the southern regions of Italy. Irrigation was supplied as needed to avoid the confounding effects of water deficit.

\section{Material and methods}

The research was carried out in 2000-2001 at the Department of Agronomy and Agroecosystem Management of the University of Pisa, Italy ( $43^{\circ}$ $40^{\prime} \mathrm{N}, 10^{\circ} 19^{\prime} \mathrm{E}$ and $1 \mathrm{~m}$ above sea level). Treatments consisted in two durum wheat varieties, Appio and Creso, three $\mathrm{N}$ fertilization rates (0, 241.4 and $362.1 \mathrm{mgN}$ pot $^{-1}$ calculated on a per surface base and corresponding to 0,120 and $180 \mathrm{~kg} \mathrm{~N} \mathrm{ha}^{-1}$ ) and two regimes of day/night air temperature during grain filling $\left(20 / 15{ }^{\circ} \mathrm{C}\right.$ and $28 / 23{ }^{\circ} \mathrm{C}$ ). The experiment was a split-plot design with three replications, with air temperature regimes during grain filling serving as main plots, varieties as subplots and $\mathrm{N}$ levels as subsubplots.

Wheat plants were grown outdoor in pots of $7 \mathrm{~L}$ volume containing $7 \mathrm{~kg}$ soil until anthesis (stage 60 of the scale of Zadoks et al., 1974). 
Soil chemical-physical properties were: $44.2 \%$ sand; $39.3 \%$ silt; $16.5 \%$ clay; $8.2 \mathrm{pH} ; 1.6 \%$ organic matter (Lotti method); $1.2 \%$ otal nitrogen (Kjeldahl method); $15.5 \mathrm{mg} \mathrm{kg}^{-1}$ available $\mathrm{P}$ (Olsen method); $72.4 \mathrm{mg} \mathrm{kg}^{-1}$ available K (Ammonium acetate method); $22.9 \%$ field capacity; $10.9 \%$ permanent wilting point. Field capacity and permanent wilting point were determined at 33 and $1500 \mathrm{kPa}$ soil water tension, using the pressure chamber method.

Ten seeds per pot were planted, and seedlings were thinned at stage 13 of the scale of Zadoks (3 leaves unfolded) to seven per pot. Pots were daily irrigated to maintain soil water content close to field capacity. Fertilizers were applied before seeding and were uniformly distributed throughout the volume of soil. Nitrogen was applied as urea. Phosphorus fertilizer (triple mineral perphosphate) and potassium, as $\mathrm{K}_{2} \mathrm{SO}_{4}$, were applied at rates of $88 \mathrm{mg} \mathrm{pot}^{-1}$ of $\mathrm{P}\left(100 \mathrm{~kg} \mathrm{ha}^{-1}\right.$ of $\left.\mathrm{P}_{2} 0_{5}\right)$ and $167 \mathrm{mg} \mathrm{pot}^{-1}$ of $\mathrm{K}$ $\left(100 \mathrm{~kg} \mathrm{ha}^{-1}\right.$ of $\left.\mathrm{K}_{2} 0\right)$.

At anthesis plants were placed in two growth chambers. Growing conditions were 14/10 h day/night photoperiod regime at $20 / 15{ }^{\circ} \mathrm{C}$ and $28 / 23{ }^{\circ} \mathrm{C}$. Lighting was provided by fluorescent lamps (Osram Fluora 77) characterized by high emission in the blue and red bands. Photosynthetic photon flux density at the top of the plant canopy was $400 \mu \mathrm{mol} \mathrm{m} \mathrm{m}^{-2} \mathrm{~s}^{-1}$ measured using a hand-held spectroradiometer model LI-1800 (LI-COR Inc., Lincoln, NE, USA). Relative humidity was kept at $65+-5 \%$.

Timing of milk, dough and physiological ripening, corresponding to stages 70,80 , and 90 of the scale of Zadoks, were recorded for each variety and $\mathrm{N}$ and temperature treatment. At anthesis and at milk, dough and physiological ripening plants were harvested for aboveground biomass determination. At each harvest, plants from three pots per treatment were cut at ground level and were separated into leaves, culms, chaff and grain and all plant parts were oven dried at $65{ }^{\circ} \mathrm{C}$ to constant weight for dry weight determination. Number of spikes per plant was determined both at anthesis and maturity, while mean kernel weight and number of kernels per spike were measured at maturity. Samples of all plant parts were analyzed for nitrogen concentration (microKjeldahl) and $\mathrm{N}$ contents were calculated by multiplying the $\mathrm{N}$ concentration by dry weight.
The duration of the period anthesis-milk ripening (A-MR), milk ripening-dough ripening (MR-DR) and dough ripening-physiological ripening (DR-PR) were calculated and expressed in days and in thermal time from anthesis. Thermal time was calculated assuming 9 ${ }^{\circ} \mathrm{C}$ as base temperature, which was found to minimize the variation in grain growth duration in the field in Italian varieties (Motzo et al., 1996). According to McMaster and Wilhelm (1997), thermal time was calculated as the sum of heat units measured in growing degree-days (GDD, ${ }^{\circ} \mathrm{Cd}$ ):

$$
\mathrm{GDD}=\left\lfloor\frac{\left(\mathrm{T}_{\mathrm{MAX}}+\mathrm{T}_{\min }\right)}{2}\right\rfloor-\mathrm{T}_{\text {BASE }}
$$

where TMAX is the daily maximum air temperature, Tmin is the daily minimum air temperature, and TBASE is the temperature below which the process does not progress. The base temperature was incorporated into the equation, if Tmin $<$ TBASE then Tmin = TBASE $($ McMaster and Wilhelm, 1997).

Data were statistically treated by ANOVA, performed separately for each harvest. At anthesis the effects of variety $(\mathrm{V}), \mathrm{N}$ rate $(\mathrm{N})$, and their interactions were tested, and at milk, dough and physiological ripening the effects of variety $(\mathrm{V}), \mathrm{N}$ rate $(\mathrm{N})$, air temperature $(\mathrm{T})$ and their interactions were tested. Duncan's multiple range test was used to separate the means when the ANOVA F-test indicated a significant effect of the treatment (Steel et al., 1997).

\section{Results}

\subsection{Duration of sub-phases during grain-filling}

The timing of anthesis was not affected by $\mathrm{N}$ rate, but it occurred 7 days earlier in Appio than in Creso. Conversely, temperature modified the whole duration of grain filling and also subphases of both varieties (Fig. 1). At $20 / 15{ }^{\circ} \mathrm{C}$ the length of the period A-MR did not vary between varieties, while the periods DR-PR and MR-DR were 5 days shorter for Creso. At 28/23 ${ }^{\circ} \mathrm{C}$ all three sub-phases during grain filling were reduced by $3-5$ days compared to $20 / 15{ }^{\circ} \mathrm{C}$. As a consequence, the increase of temperature from $20 / 15{ }^{\circ} \mathrm{C}$ to $28 / 23{ }^{\circ} \mathrm{C}$ decreased the grain filling period of Appio by 25 days and the one 
Appio
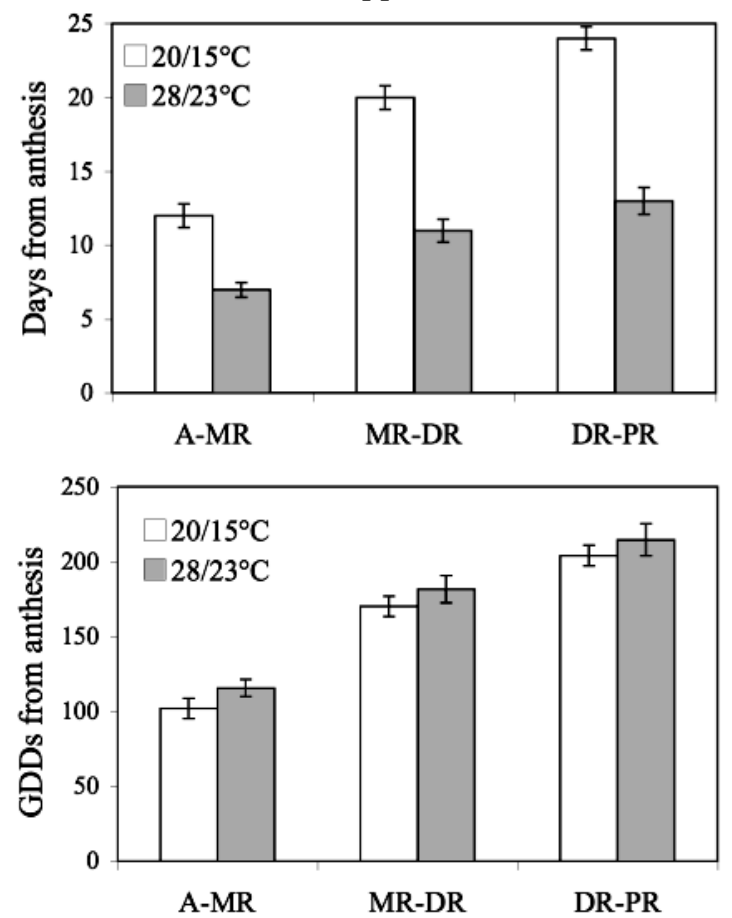

Creso
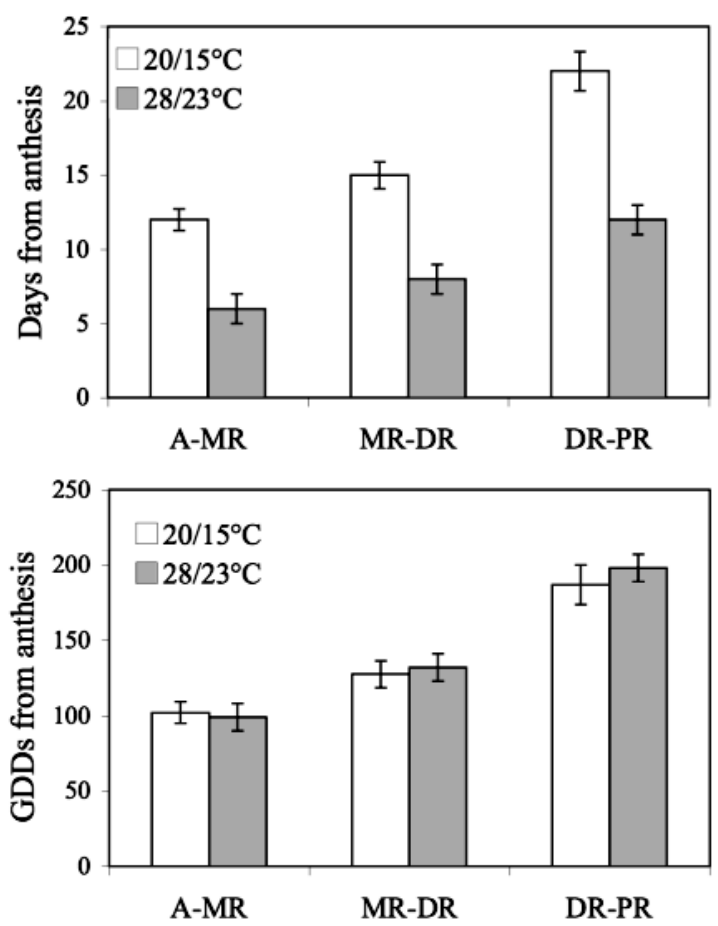

Figure 1. Duration of the periods anthesis - milk ripening (A-MR), milk ripening - dough ripening (MR-DR) and dough ripening - physiological ripening (DR-PR) of Appio and Creso expressed in days (up) and in GDD from anthesis (down). In these and in the following figures, vertical bars indicate standard error. When not shown, error bar lies within the symbol.

of Creso by 23 days. However, when expressed in GDD, the duration of either the whole grain filling or of the periods within this phase was not appreciably modified by temperature regimes in both varieties (Fig. 1).

Expressed either in days or in GDD, the period A-MR accounted for $23 \%$ of the whole grain filling period in both varieties, MR-DR for $35 \%$ in Appio and 31\% in Creso, and DR-PR for the remaining $42 \%$ in Appio and $46 \%$ in Creso.

\subsection{Grain yield and yield components}

At maturity, grain yield of both varieties was affected by the interaction of variety, $\mathrm{N}$ rate and temperature regime (Fig. 2). The increase of $\mathrm{N}$ rate increased grain yield of Appio and Creso at both temperatures, but increases were higher at the lower regime. Thus, with N0 grain yield of both varieties did not differ in response to temperature, while with $\mathrm{N} 120$ and N180 it was lower at $28 / 23{ }^{\circ} \mathrm{C}$, compared to $20 / 15^{\circ} \mathrm{C}$. Moreover, with all $\mathrm{N}$ rates, grain yield of the two varieties was similar at $28 / 23{ }^{\circ} \mathrm{C}$, while at $20 / 15{ }^{\circ} \mathrm{C}$ grain yield of Appio was $16 \%$ higher than that of Creso.

Differences in grain yield resulted from differences in kernel number per spike and in mean kernel weight. In both varieties, the number of kernels per spike was not affected by temperature and increased due to nitrogen fertilizer by $163 \%$ with $\mathrm{N} 120$ and by $267 \%$ with N180. Moreover, the number of kernels per spike differed between varieties: averaged over temperatures and $\mathrm{N}$ rates, the value of Appio was $42 \%$ higher than the one of Creso (Fig. 2). Conversely, mean kernel weight was only affected by the interaction of temperature and $\mathrm{N}$ rate (Fig. 2). At $28 / 23{ }^{\circ} \mathrm{C}$ mean kernel weight was practically unaffected by $\mathrm{N}$ fertilization, while at $20 / 15^{\circ} \mathrm{C}$ it increased with the increase of $\mathrm{N}$ rate from 0 to $120 \mathrm{~kg} \mathrm{ha}^{-1}$ and was not further modified by $180 \mathrm{~kg} \mathrm{~N} \mathrm{ha}^{-1}$. Finally, the mean kernel weight of unfertilized plants was by $12 \%$ higher at $20 / 15{ }^{\circ} \mathrm{C}$ compared to $28 / 23{ }^{\circ} \mathrm{C}$, and that of plants fertilized with 120 and $180 \mathrm{~kg} \mathrm{~N}$ ha $^{-1}$ was by $36-41 \%$ higher. 


\subsection{Accumulation of dry matter during grain filling}

During grain filling, the time trend of dry matter accumulation in grain, leaves, culms and chaff of Appio and Creso greatly differed among treatments (Fig. 3). For both varieties, grain dry weight increased from A to DR, while after DR it did not change or only slightly increased. The rate of accumulation in grain was higher for Appio and in both varieties it increased with the increase of $\mathrm{N}$ rate. Temperature had little, if any, effect on grain accumulation in unfertilized plants of both varieties. With 120 and $180 \mathrm{~kg} \mathrm{~N} \mathrm{ha}^{-1}$, the accumulation of dry matter in grain of the two varieties was similar at $28 / 23{ }^{\circ} \mathrm{C}$, while at $20 / 15^{\circ} \mathrm{C}$ values of Appio were greater than those of Creso. Differences between varieties were established in the period MR-DR, when the rate of dry weight accumulation per day was up to $71 \%$ higher for Appio, with greater differences at N0 (Tab. 1).

The pattern of accumulation of dry matter in chaff differed from that in grain, in that it occurred mainly before anthesis, and was small thereafter (Fig. 3). The increase of $\mathrm{N}$ rate from N0 to N120 increased chaff dry weight over 4 fold in Appio and over 3 fold in Creso at all stages, while the increase of $\mathrm{N}$ rate from $\mathrm{N} 0$ to N180 increased it over 5 fold in both varieties. In fertilized plants, values of chaff were higher at $20 / 15{ }^{\circ} \mathrm{C}$ than at $28 / 23{ }^{\circ} \mathrm{C}$, while in unfertilized ones temperature was ineffective.

Opposite to grain and chaff, the dry weight of leaves and culms of both Appio and Creso decreased during grain filling with all $\mathrm{N}$ rates and temperatures. Nitrogen fertilization at both rates increased values before anthesis, while during grain filling differences among $\mathrm{N}$ rates were unchanged. Temperature did not modify the growth pattern. Unfertilized plants of the two varieties showed similar values during grain filling, while fertilized plants of Creso had higher values of culm and leaf biomass at all stages. At anthesis, plants of Creso fertilized with N180 had $24 \%$ higher leaf biomass and $16 \%$ higher culm biomass compared to Appio.

\subsection{Accumulation of nitrogen during grain filling}

Between MR and PR the nitrogen concentration in grain of Appio and Creso was practical-
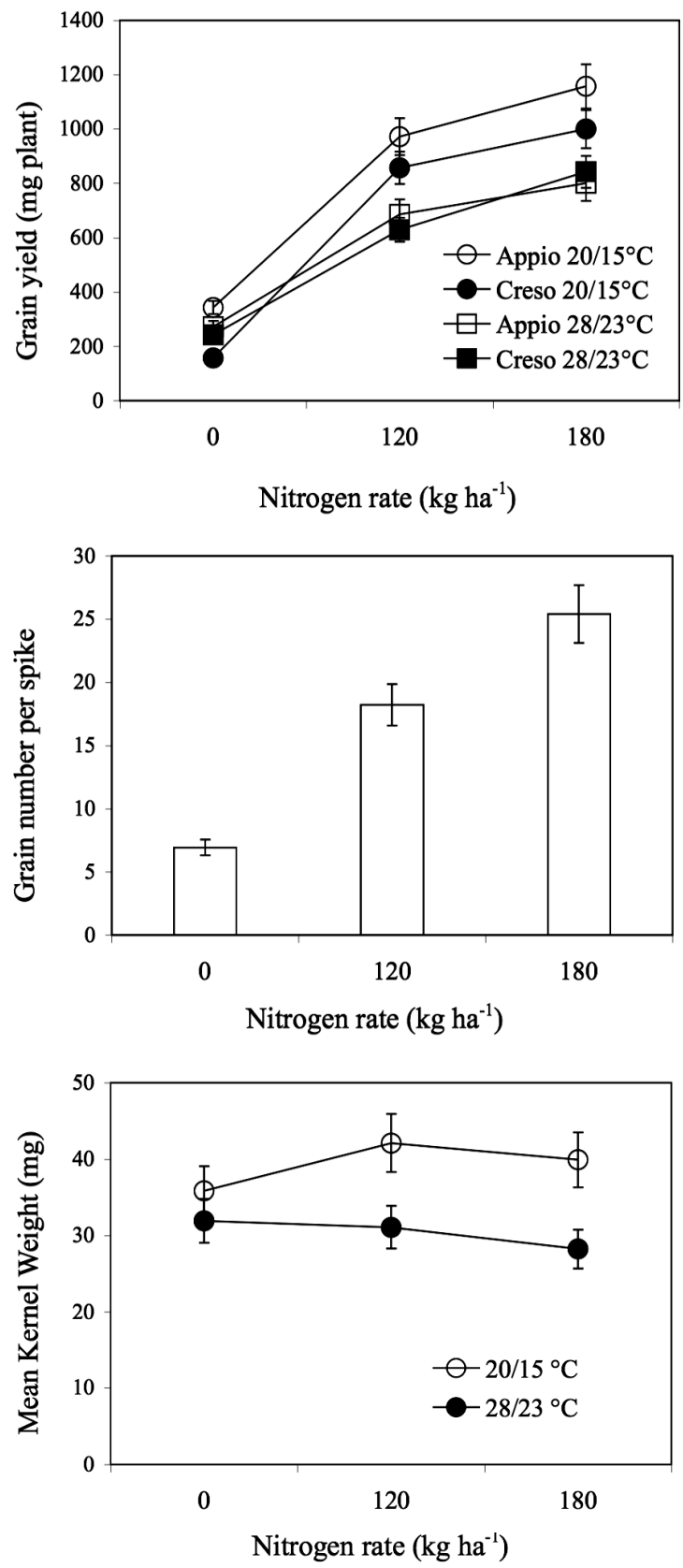

Figure 2. Grain yield of Appio and Creso, genotype $\mathrm{x} N$ rate $\mathrm{x}$ temperature regime interaction (up); grain number per spike, $\mathrm{N}$ rate mean effect (centre); and mean kernel weight, $\mathrm{N}$ rate $\mathrm{x}$ temperature regime interaction (down).

ly unchanged in plants kept at $20 / 15^{\circ} \mathrm{C}$ and only slightly increased at $28 / 23{ }^{\circ} \mathrm{C}$ (Fig. 4). At all stages and for both varieties, the effect of temperature was higher than that of $\mathrm{N}$ rate: $\mathrm{N}$ concentration increased owing to the increase of 
Table 1. Rate of dry weight accumulation $\left(\mathrm{mg} \mathrm{GDD}^{-1}\right.$ plant $\left.^{-1}\right)$ in grain during the main developmental phases of grain filling of Appio and Creso.

\begin{tabular}{lrrccccc}
\hline Temperature & N rate & \multicolumn{3}{c}{ Appio } & \multicolumn{2}{c}{ Creso } \\
& & A-MR & MR-DR & DR-PR & A-MR & MR-DR & DR-PR \\
\hline $20 / 15{ }^{\circ} \mathrm{C}$ & 0 & $1.4 \mathrm{a}$ & $1.2 \mathrm{ab}$ & - & $1.6 \mathrm{a}$ & $0.7 \mathrm{a}$ & - \\
& 120 & $4.3 \mathrm{~b}$ & $2.9 \mathrm{c}$ & $0.2 \mathrm{a}$ & $4.1 \mathrm{~b}$ & $2.6 \mathrm{bc}$ & $0.6 \mathrm{a}$ \\
& 180 & $5.2 \mathrm{~b}$ & $3.1 \mathrm{c}$ & $0.5 \mathrm{a}$ & $5.6 \mathrm{~b}$ & $2.8 \mathrm{c}$ & $0.4 \mathrm{a}$ \\
$28 / 23^{\circ} \mathrm{C}$ & 0 & $1.0 \mathrm{a}$ & $0.7 \mathrm{a}$ & $0.1 \mathrm{a}$ & $1.4 \mathrm{a}$ & $0.5 \mathrm{a}$ & $0.1 \mathrm{a}$ \\
& 120 & $3.5 \mathrm{~b}$ & $1.7 \mathrm{~b}$ & $0.1 \mathrm{a}$ & $3.9 \mathrm{~b}$ & $1.8 \mathrm{~b}$ & - \\
& 180 & $3.7 \mathrm{~b}$ & $2.0 \mathrm{bc}$ & - & $4.6 \mathrm{~b}$ & $2.1 \mathrm{~b}$ & $0.5 \mathrm{a}$ \\
\hline
\end{tabular}

Within columns, numbers followed by the same letter are not significantly different at $P \leq 0.05$.

temperature and $\mathrm{N}$ rate, but at all three $\mathrm{N}$ rates it was higher in plants kept at $28 / 23{ }^{\circ} \mathrm{C}$.

Opposite to grain, $\mathrm{N}$ concentration in chaff, leaves and culms declined during grain filling. The increase of $\mathrm{N}$ rate increased $\mathrm{N}$ concentration at anthesis and these differences were maintained during grain filling. Temperature increased $\mathrm{N}$ concentration at all stages and the effect of temperature was negligible in unfertilized plants and increased with the increase of $\mathrm{N}$ rate. Between varieties, differences due to $\mathrm{N}$ fertilization were higher in chaff and culms of Appio compared to Creso: at anthesis N concentration in chaff of Appio fertilized with N180 increased by $50 \%$ compared to $\mathrm{N} 0$ and $\mathrm{N}$ concentration in culms increased by $85 \%$. Corresponding increases in Creso were $26 \%$ and $33 \%$, respectively. Conversely, the effect of $\mathrm{N}$ fertilization in leaves was similar in the two varieties.

During grain filling, the total $\mathrm{N}$ content of grain increased at all $\mathrm{N}$ rates and temperatures from anthesis to DR. From DR to PR it did not change in unfertilized plants at both temperatures, and slightly increased in fertilized ones (Fig. 5). Temperature had no impact on grain $\mathrm{N}$ content of unfertilized plants of both varieties, while in fertilized plants the effect of temperature was different in the two varieties. Grain N content of Appio was practically unaffected by temperature, while the one of Creso was lower at $20 / 15{ }^{\circ} \mathrm{C}$ compared to $28 / 23{ }^{\circ} \mathrm{C}$. As a consequence, at $\mathrm{PR}$ grain $\mathrm{N}$ content of plants of Creso fertilized with $120 \mathrm{~kg} \mathrm{~N} \mathrm{ha}^{-1}$ was $16 \%$ lower at $20 / 15{ }^{\circ} \mathrm{C}$ than at $28 / 23{ }^{\circ} \mathrm{C}$ and that of plants fertilized with $180 \mathrm{~kg} \mathrm{~N}^{-1}$ was $30 \%$ lower.

Conversely, as grain filling proceeds, $\mathrm{N}$ content of chaff, leaves and culms declined pro- gressively, evidencing an export of $\mathrm{N}$ from vegetative plant part. Nitrogen fertilization increased $\mathrm{N}$ content in all plant parts starting from anthesis, and the differences due to $\mathrm{N}$ rate decreased during grain filling. Thus, the export of $\mathrm{N}$ was higher with the increase of $\mathrm{N}$ rate. The effect of temperature was different in the various plant parts of both varieties: differences were low in culms, while in chaff and leaves the higher temperature increased $\mathrm{N}$ content. However, the increase was negligible in unfertilized plants, and was appreciable in fertilized ones.

\section{Discussion}

In our research, the duration of the intervals between the main maturity stages within grain filling were both genotype-specific and temperature-dependent but they were not affected by $\mathrm{N}$ availability. In Italy, the transition from the oldest durum wheat varieties to the more recent varieties was characterized by an earlier anthesis (Motzo et al., 2004). Thus, anthesis of the more recent Appio occurred 7 days earlier compared to the older variety Creso. However, for Appio the grain filling period was by 7 days longer at $20 / 15^{\circ} \mathrm{C}$ and by 4 days longer at $28 / 23$ ${ }^{\circ} \mathrm{C}$ and, consequently, the length of the whole biological cycle was practically unchanged for Appio and Creso. In particular, the elongation of the grain filling period was achieved in Appio by the longer duration of the period DRMR. The two genotypes responded to the higher temperature regime by increasing the rate of development, which shortened the time to complete grain filling. However, the thermal time of 


\section{Appio}
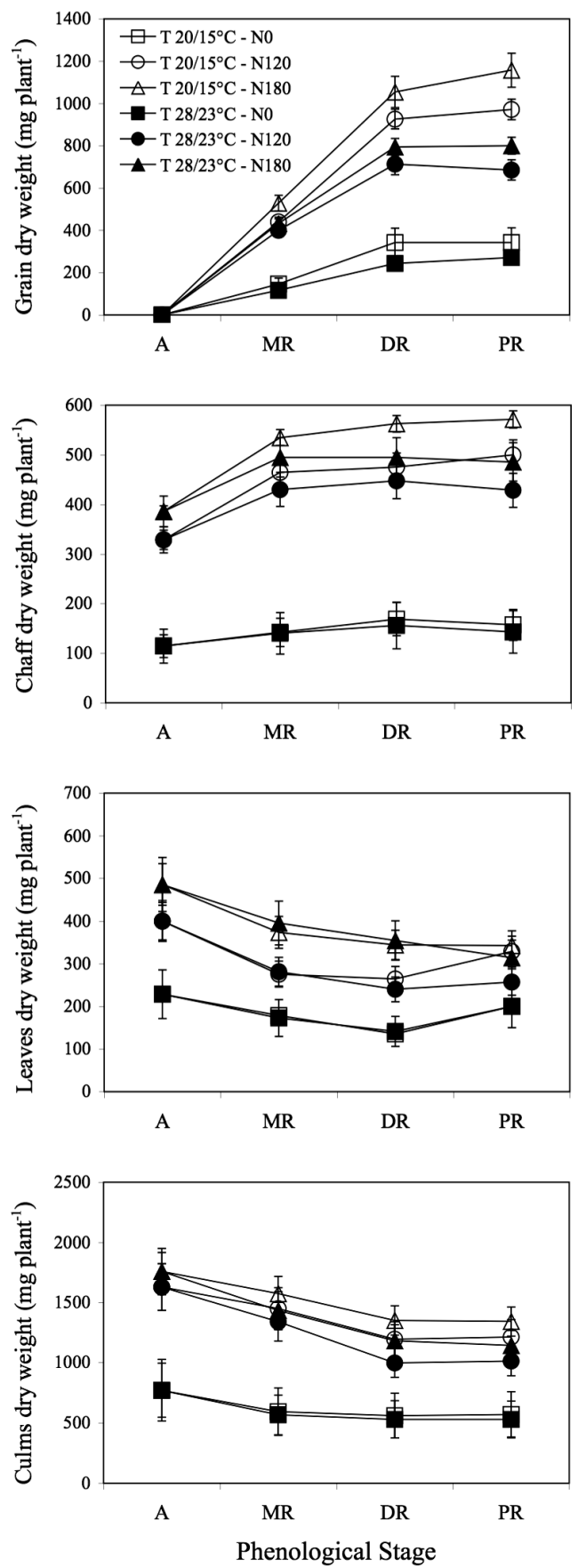

Creso
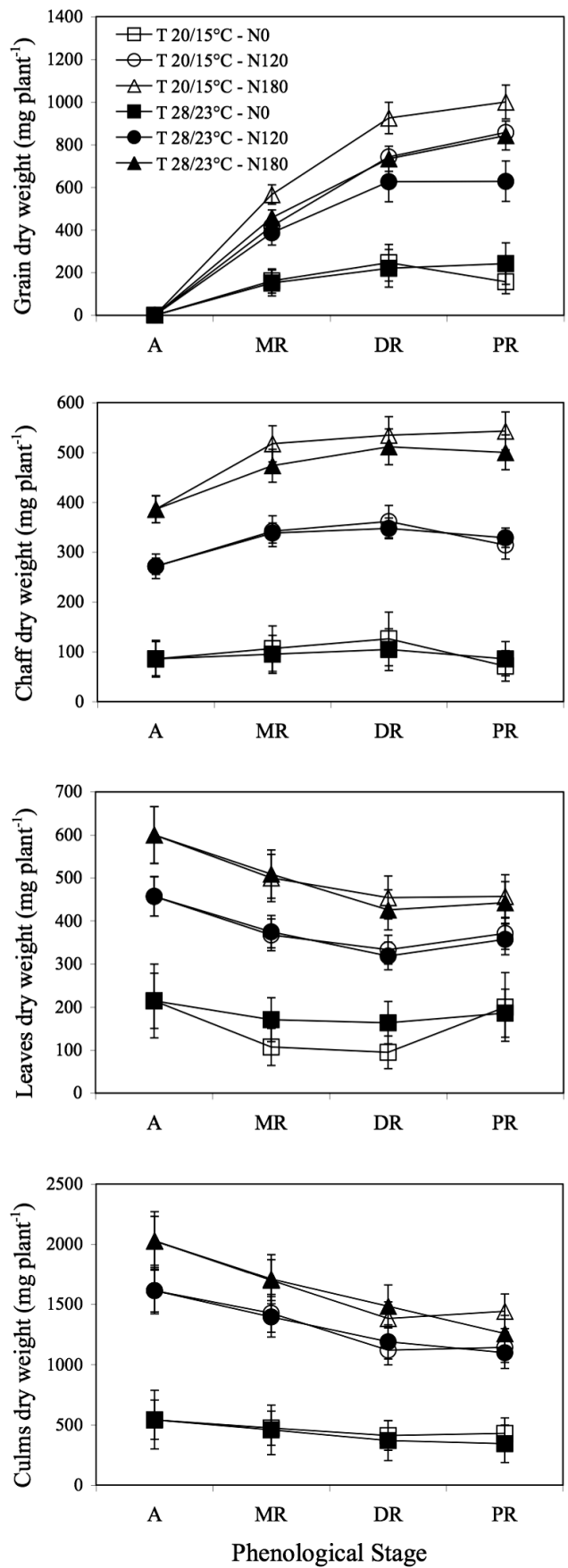

Figure 3. Dry weight of grain, chaff, leaves and culms of Appio and Creso under the two temperature regimes at anthesis (A), milk ripening (MR), dough ripening (DR) and physiological ripening (PR).

development was unchanged with the two temperature treatments. Thus, the duration of the grain filling stages was determined for each va- riety by temperature. This result confirm that the period from anthesis to maturity in wheat is considered to be sensitive to temperature and 


\section{Appio}
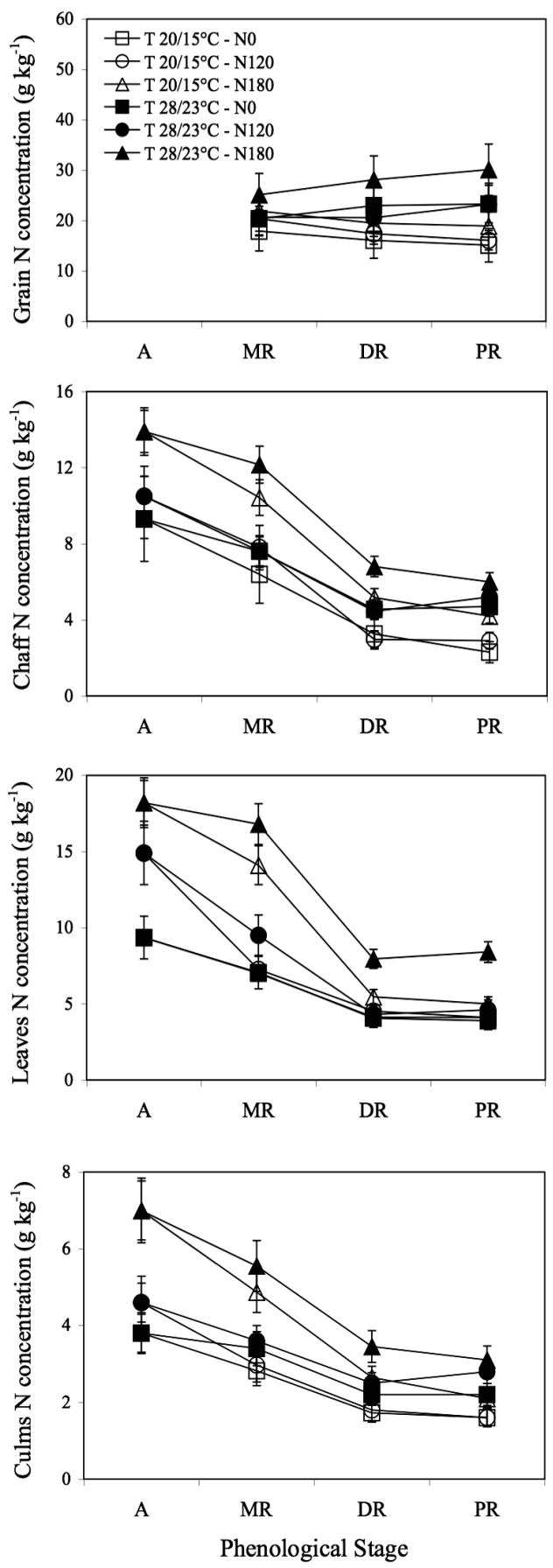

Creso
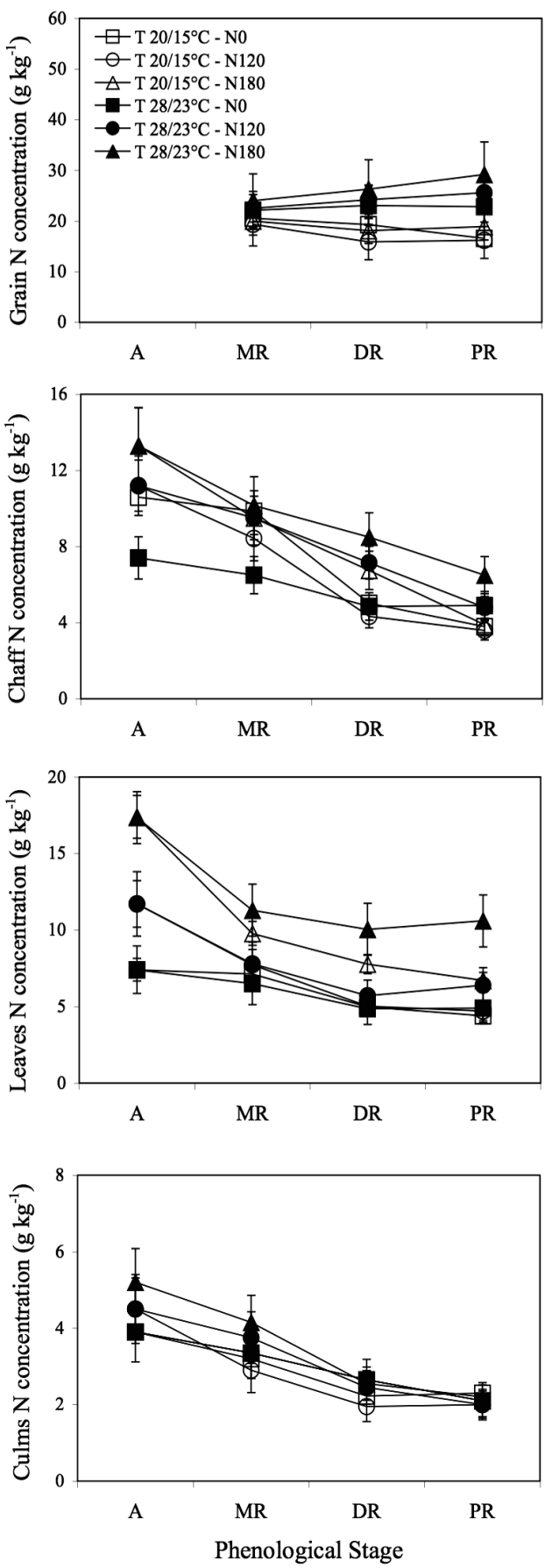

Figure 4. Nitrogen concentration of grain, chaff, leaves and culms of Appio and Creso under the two temperature regimes at anthesis (A), milk ripening (MR), dough ripening (DR) and physiological ripening (PR).

insensitive to both photoperiod and vernalization (Slafer and Rawson, 1994).

Following Triboi and Triboi-Blondel (2002), the duration of grain filling is controlled, in addition to air temperature, also by plant nutrient status and reproductive sink demand for assimi- 


\section{Appio}
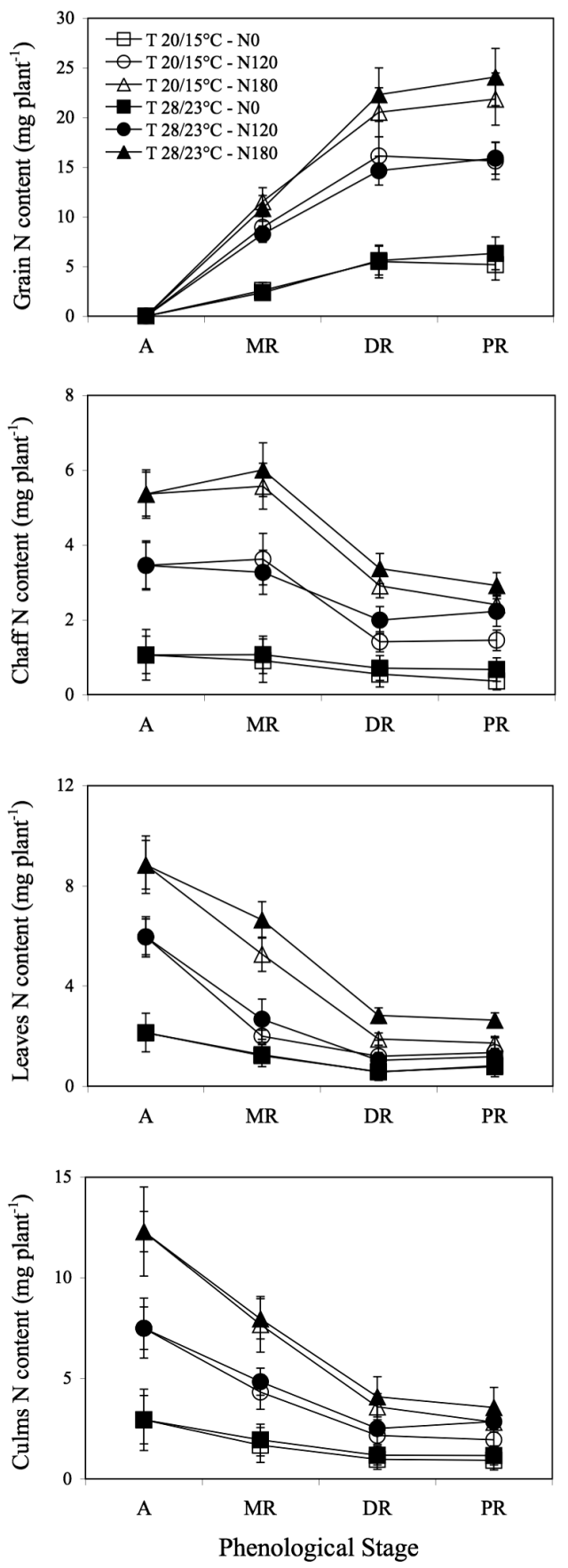

\section{Creso}
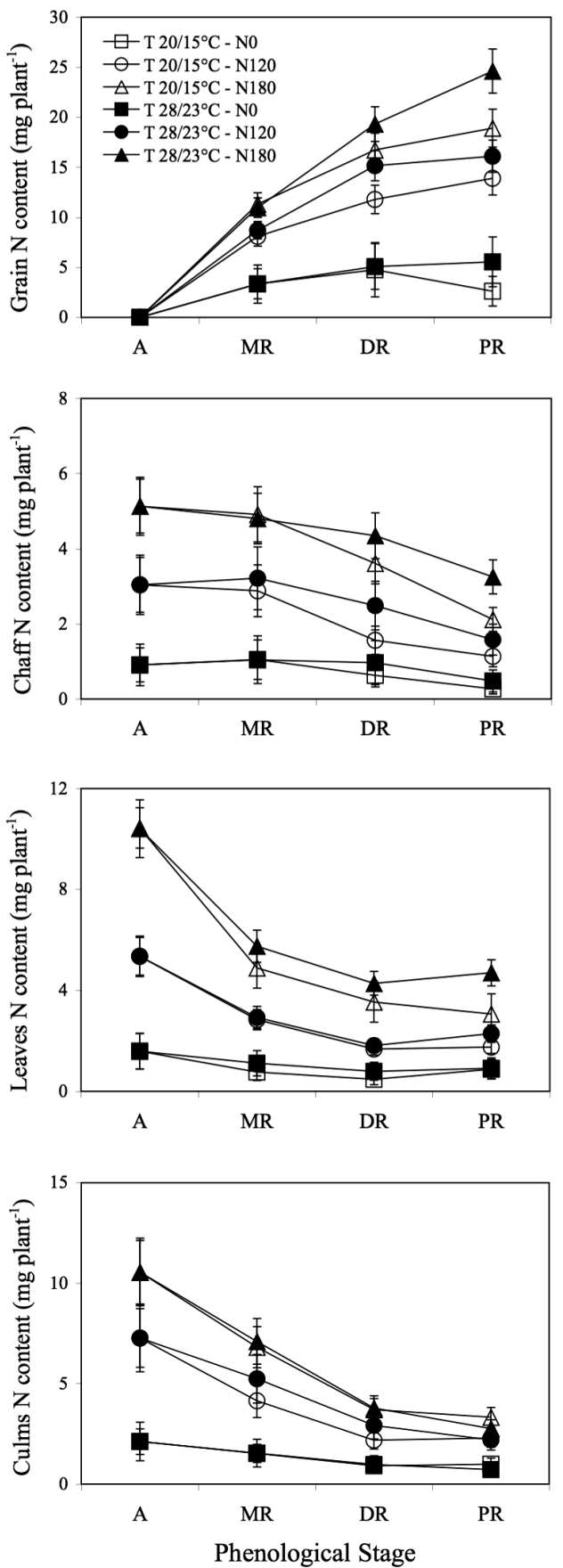

Figure 5. Nitrogen content of grain, chaff, leaves and culms of Appio and Creso under the two temperature regimes at anthesis (A), milk ripening (MR), dough ripening (DR) and physiological ripening (PR).

late. The $\mathrm{N}$ status of the plant and the rate of $\mathrm{N}$ demand by the developing grain was found to affect leaf senescence which, in turn, controls the duration of grain filling. Thus, rapid leaf senescence occurring during grain filling is likely to indicate a reduced $\mathrm{N}$ uptake caused by the 
depletion of available soil N. In our research, $\mathrm{N}$ rate did not modify the timing of grain development of both varieties. Consequently, we can argue that the demand for $\mathrm{N}$ by grain was completely satisfied by either the active uptake of $\mathrm{N}$ from soil or the remobilization of $\mathrm{N}$ from vegetative tissue.

Grain weight is the last yield component to be formed during wheat cycle, as grain growth occurs during grain filling. Our results showed that grain growth was reduced by the higher temperature, while $\mathrm{N}$ accumulation in grain was reduced by the lower temperature. However, these effects were recorded only in fertilized plants. Nitrogen availability modified the growth of the plant during the whole cycle, in that increased $\mathrm{N}$ fertilizer at seeding resulted in a greater plant size at anthesis and in a greater accumulation rate of dry matter and $\mathrm{N}$ in grain during grain filling. Moreover, the decline of dry matter and $\mathrm{N}$ in vegetative plant parts increased with the increase of $\mathrm{N}$ fertilization. Thus, the higher was the $\mathrm{N}$ rate, the greater was the export of $\mathrm{N}$ to grain. The decline of dry matter and $\mathrm{N}$ content in chaff, leaves and culms during grain filling has always been interpreted as resulting from remobilization of dry matter and nitrogen from vegetative plant parts to grain (Cox et al., 1985; Asseng and van Herwaarden, 2003; Pampana et al., 2007). Consequently, N fertilization increased the amount of dry matter and $\mathrm{N}$ remobilized from vegetative plant parts to grain during grain filling.

Grain yield differed between varieties: at optimal temperature, grain yield of Appio was $16 \%$ higher than Creso, owing to a greater accumulation rate in the period MR-DR, when Appio had 50-140\% higher values. Conversely, Creso sustained a smaller reduction in grain dry weight under high temperature. Grain yield of fertilized plants of Creso was reduced by only $21 \%$ in response to high temperature, while it was reduced by up to $55 \%$ in Appio. Nitrogen content in grain showed an opposite pattern: grain $\mathrm{N}$ content of Appio was practically unaffected by temperature, while the one of Creso was increased at the $28 / 23{ }^{\circ} \mathrm{C}$ regime. Therefore, Creso appears to be more heat tolerant than Appio.

In conclusion, we have shown that temperature and nitrogen fertilization affected growth, accumulation and partitioning of dry matter and
$\mathrm{N}$ in durum wheat that, in turn, affected grain yield and $\mathrm{N}$ content. Grain yield and kernel weight were better expressed at $20 / 15^{\circ} \mathrm{C}$, while grain protein concentration was favoured under the $28 / 23{ }^{\circ} \mathrm{C}$ temperature regime. We can argue that in absence of water shortage, rainfed conditions in the south of Italy are likely to offer the best opportunity for production of durum wheat of good quality. Nitrogen fertilization increased the sensitivity of plants to high temperature. Thus the role of $\mathrm{N}$ fertilization under heat stress may be more important than under optimal temperatures.

\section{References}

Alkhatib K., Paulsen G.M. 1992. Photosynthesis and productivity under high-temperature stress of wheat genotypes from major world regions. Crop Sci., 30:1127-1132.

Altenbach S.B., DuPont F.M., Kothari K.M., Chan R., Johnson E.L., Lieu D. 2003. Temperature, water and fertilizer influence the timing of key events during grin development in a US spring wheat. J. Cereal Sci., 37:9-20.

Asseng S., van Herwaarden A.F. 2003. Analysis of the benefits to wheat yield from assimilates stored prior to grain filling in a range of environments. Plant Soil, 256:217-229.

Blum A. 1994. The effect of heat stress on leaf and ear photosynthesis. J. Exp. Bot., 37:111-118.

Burke J.J., Mahan J.R., Hatfield J.L. 1988. Crop-specific thermal kinetic windows in relation to wheat and cotton biomass production. Agron. J., 80:553-556.

Chowdury S.I., Wardlaw I.F. 1978. The effect of temperature on kernel development in cereals. Aust. J. Agric. Res., 29:205-223.

Cox M.C., Qualset C.O., Rains D.W. 1985. Genetic variation for nitrogen assimilation and translocation in wheat. I. Dry matter and nitrogen accumulation. Crop Sci., 25:430-435.

Guedira M., Paulsen G.M. 2002. Accumulation of starch in wheat grain under different shoot/root temperatures during maturation. Funct. Plant Biol., 29:495-503.

McMaster G.S., Wilhelm WW. 1997. Growing degreedays: one equation, two interpretations. Agric. For. Meteorol., 87:291-300.

Motzo R., Giunta F., Deidda M. 1996. Relationships between grain-filling parameters, fertility, earliness and grain protein of durum wheat in a Mediterranean environment. Field Crops Res., 47:129-142.

Pampana S., Mariotti M., Ercoli L., Masoni A. 2007. Accumulation and remobilization of dry matter, nitrogen and phosphorus in durum wheat as affected by genotype and environment. Ital. J. Agron., 2:3-13. 
Panozzo J.F., Eagles H.A. 1999. Rate and duration of grain filling and grain nitrogen accumulation of wheat cultivars grown in different environments. Aust. J. Agric. Res., 50:1007-1015.

Peterson C.J., Graybosh R.A., Shelton D.R., Baenziger P.S. 1998. Baking quality of hard red winter wheat: response of cultivars to environment in the Great Plains. Euphytica, 100:157-162.

Plaut Z., Butow B.J., Blumenthal C.S., Wrigley C.W. 2004. Transport of dry matter into developing wheat kernels and its contribution to grain yield under postanthesis water deficit and elevated temperature. Field Crops Res., 86:185-198.

Porter J.R., Gawith M. 1999. Temperatures and the growth and development of wheat: a review. Eur. J. Agron., 10:23-36.

Slafer G.A., Rawson H.M. 1994. Sensitivity of wheat phasic development to major environmental factors: a reexamination of some assumptions made by physiologists and modellers. Aust. J. Plant Physiol., 21:393-426.

Sofield I., Evans L.T., Cook M.G., Wardlaw I.F. 1977. Factors influencing the rate and duration of grain filling in wheat. Aust. J. Plant Physiol., 4:785-797.

Steel R.G.D., Torrie J.H. 1980. Principles and procedures of statistics. $2^{\text {nd }}$ ed. McGraw-Hill, New York.

Stone P.J., Nicholas M.E. 1995. A survey of the effects of high temperature during grain filling on yield and quality of 75 wheat cultivars. Aust. J. Agric. Res., 46:475-492.

Tashiro T., Wardlaw I.F. 1989. A comparison of the ef- fect of high temperature on grain development in wheat and rice. Ann. Bot., 64:59-65.

Triboi E., Triboi-Blondel A.M. 2002. Productivity and grain or seed composition: a new approach to an old problem - invited paper. Eur. J. Agron., 16:163-186.

Vaccari F.P., Ranieri R., Matese A., Miglietta F. 2007. Enhanced temperature during grain filling reduces protein concentration of durum wheat. Ital. J. Agron., 4:393-400.

Wardlaw I.F. 1974. Temperature control of translocation. Bull. Roy. Soc. New Zea., 12:533-538.

Wardlaw I.F., Dawson I.A., Munibi P. 1989. The tolerance of wheat to high temperatures during reproductive growth. II. Grain development. Aust. J. Agric. Res., 40:15-24.

Wardlaw I.F., Moncur L. 1995. The response of wheat to high temperature following anthesis. I. The rate and duration of kernel filling. Aust. J. Plant Physiol., 22:391-397.

Wardlaw I.F., Sofield I., Cartwright P.M. 1980. Factors limiting the rate of dry matter accumulation in the grain of wheat grown at high temperature. Aust. J. Plant Physiol., 7:387-400.

Wiegand C.L., Cuellar J.A. 1981. Duration of grain filling and kernel weight of wheat as affected by temperature. Crop Sci., 21:95-101.

Zadoks J.C., Chang T.T., Konzak C.F. 1974. A decimal code for the growth stages of cereals. Weed Res., 14:415-421. 